\title{
The Effect of Mobile English Learning Center to Teacher's Ability, English Proficiency and Attitude of Students in Remote Areas
}

\author{
Wanida Simpol a1, Loei Primary Educational Service Area Office 2, Wangsaphung, Loei \\ 42130, Thailand \\ Phoom Praraksa b , Samutprakan Primary Educational Service Area Office 1, Muang, \\ Samutprakan 10270, Thailand \\ Prakit Singthong ${ }^{\mathrm{c}}$, Jiarawanon-Utis $4^{\text {th }}$ School, Wangsaphung, Loei 42130, Thailand \\ Paulina, M. Pd ${ }^{\mathrm{d}}$, Universitas Muhammadiyah Gresik, East Java 61121, Indonesia
}

\begin{abstract}
Inequality in education is an important problem in Thailand, especially English learning between urban and rural students that concerned teacher quality, socioeconomic status of students, and English learning support system that directly affects the quality of English learning. This research aimed to develop teachers' ability in teaching English, English proficiency, and Attitude of primary students in Loei Primary Educational Service Area Office 2 located in the remote area of Thailand using Mobile English Learning Center based on an activity-based learning approach. The study conducted 2 phases in the academic year 2019 with the 157 affiliated schools comprising of 130 teachers and 1,482 students. The quantitative and qualitative data were collected through questionnaires, English skills assessment, observation, interview, and reflection meetings. Descriptive statistics were applied for quantitative data, Z-test, and one sample t-test for hypothesis testing and content analysis for qualitative data. The result of this research indicated that the treatment affected teachers' ability in teaching English, English proficiency, and Attitude of the students with the statistical significance, and also achieved the student attitude toward the English learning. The implication and recommendations were also discussed.
\end{abstract}

Keywords: Mobile English Learning Center, Active Learning, Activity-Based Learning, LearnerCentered, Teacher Development;

\section{INTRODUCTION}

Inequality in education is one of the most fundamental problems for Thai society. Quality education is an opportunity that helps people improve their quality of life in the long run. People who do not have access to education are often caught in the trap of poverty which affects generation to generation. Information from the Fund for Educational Equality indicates that currently, there are over 6.7 hundred thousand children in Thailand who have dropped out of the education system, representing an economic opportunity cost of around 300 billion baht, or about $3 \%$ of GDP. Thai society still has more than 2 million children at risk of falling out of education just because they are from low-income families with lacking opportunities. There are only $5 \%$ of children from impoverished families who can study at the higher education level. Not to mention the disparity in the quality of education between the city and the countryside, between big schools and small schools, and between different schools, including teacher quality problems and many teaching and learning problems (The One O One, 2020). This was consistent with the data from the symposium for listening to stakeholders' opinions created the draft of the Thai Educational Conditions Report 2017-2018, which reported that Thais had accessed more than 90\% of compulsory education. However, there was a quality disparity between city schools and countryside schools. People from

\footnotetext{
* ADDRESS FOR CORRESPONDENCE: Wanida, Simpol, Loei Primary Educational Service Area Office 2, Thailand
}

E-mail address: wanidaloei2@gmail.com Tel.: (+66)86-218-3746 
good income families had accessed to better quality education than those from low-income families (Education Council, 2018). Moreover, Leeahtam (2020) said that the children whose parents are willing to send their children to a prestigious school do not attend the local school. People with low incomes have to send their children to local schools in order to make children access technology and have more opportunities to learn, including the opportunities for learning English. This is one example that is a reflection of the inequality that affects education. In addition, the results of a national English language test showed that urban children scored significantly higher than in the countryside, which is an advantage for children in cities who have more places to study with wealthier parents. The urban children can develop their quality more than students who do not access facilities due to economic factors or areas. Therefore, it is no surprise that the test score results for the city and rural students are different.

As the disparity between English language education of urban children and rural children, it is an important task of how to improve the English language skills of rural students equal to urban students. The Ministry of Education pays attention to teaching and learning English because English is a universal language which makes it an important language in the world. The use of English for communication is an essential skill in the $21^{\text {st }}$ century. To develop learners to have the potential and skills to use English is necessary to do. Thus, the Ministry of Education encourages schools to manage their own education policy. Teaching English with a standard by choosing the educational management model is considered appropriate following the conditions, context, and readiness of the school with various different forms of operation (Office of the Basic Education Commission, 2014). In addition, it also establishes strategies for production, development of manpower, and competitiveness. The main guidelines for production, manpower development, and research are raising the standard, developing language curriculum and English teachers, and upgrading English learning to support Thailand 4.0 (Ministry of Education, 2017). English communication ability of the population in the country is an important factor for trade, innovation, and national income as well. This makes the value of English learning helps significantly in the growth of the country (Grenier, 2015). If the English usage is quite low, the country's potential in various fields will be affected, according to the top 5 countries with the lowest English proficiency, namely Colombia, Panama, Saudi Arabia, Thailand, and Libya (Sriyai, 2012).

Recently, Thai children had the opportunity to learn English from both teachers and various media. They experienced and developed English more than in the past. However, the result obtained by the National Institute of Educational Testing Service (Public Organization) showed that English subject is still in the subject with the lowest average (mean $=23.98$ ). The important problem was the English skill of teachers were not practical. Some schools required teachers who did not have an area of study in English to teach English. The condition where English is taught by non-English major teachers happens in most the primary schools in Thailand (Doungprom, Phusee-on, \& Prachanant, 2016). It caused problems. Teachers had a lack of confidence in teaching and a lack of proper English teaching techniques. The number of English teachers in each school was not balanced with the number of students. Personally, students had a bad attitude towards learning English. They thought that English was difficult and did not want to learn it. In addition, the curriculum was not favorable too (Bangkok Biznews, 2016). The teachers' problems are still having a lack of basic knowledge of English, especially in vocabulary, grammar, and pronunciation, which affected the communication and teaching process due to their lack of English teaching qualifications (Charoenpho, Supanyo, \& Tinangwattana, 2016).

In the context of learning English in Loei province, it was found that students were short of skills in English reading and writing. The national test results for the academic year 2017 showed an average score lower than the national standard criteria (Loei Provincial Education Office, 2018).

71 | IJET| Volume. 10, Issue 1. July 2021 
For Loei Primary Educational Service Area Office 2, there were problems of small schools with incomplete teachers for 95 schools from 157 affiliated schools accounting for $60.51 \%$, including lacking major English teachers. The average of the Ordinary National Educational Test (O-NET) for the academic year 2017 of Prathomsuksa 6 students (Grade 6) was $28.08 \%$, while the Mathayomsuksa 3 students (Grade 9), the average of the Ordinary National Educational Test (ONET) was $26.88 \%$. Both levels were lower than the national average. In addition, there were quality problems such as inadequate teachers, lack of confidence in English communication, and problems in using English in the classroom, including the use of teaching techniques that stimulate students' interest. Students themselves had a lousy attitude toward English Learning, lack of motivation, and fear of learning English (Loei Primary Educational Service Area Office 2, 2018).

Such a problem points out that the teaching of English in Thailand should be resolved urgently. Otherwise, the investment of time and budget in learning English will be wasted. As a result, Loei Primary Educational Service Area Office 2 designed the Mobile English Learning Center based on an activity-based learning approach to develop the English proficiency and Attitude of primary students in Loei PESAO 2, located in the remote area of Thailand.

\section{METHOD}

The study conducted 2 phases in the academic year 2019 with the 157 affiliated schools comprising of 130 teachers and 1.482 students. The first phase was designed as a pilot study in Phuluang, a district of Loei province, in the first semester, and the second phase was expanded, covering 6 districts in Loei PESAO 2.

\section{Phase 1: Pilot Study \\ 1.1 Participants}

The participants were 144 Prathomsuksa 6 (Grade 6) students, 30 teachers from 9 schools consisting of Chumchonbannongkhan School, BanOom School, Kaengsripoom School, Nadindam School, Suanpor School, Namoontun School, Huaisisiad School, Sabjaroen School, and Wangnamphu School in Phuluang district. The sample size was determined using the Krejcie \& Morgan formula at a 95\% of confidence level. Purposive sampling was used to select the sample for the pilot study in the first semester of the academic year 2019.

\subsection{Measurement}

\subsubsection{Treatment: Mobile English Learning Center}

Mobile English Learning Center is a local curriculum focusing on Activity-Based Learning, which is a learning approach in the $21^{\text {st }}$ century based on experience-based Learning or Experiential Learning. "Activity" is the main thing to learn by using various formats. This method of Learning is based on the learners center. Teachers and students may consult each other to carry out activities for learning experiences in the development of life skills and academic Learning. Activity-Based Learning is a learning method that focuses on the role and participation of learners or Active Learning, which means a teaching style is encouraging learners to participate in Learning. The activity is based on student-teacher interaction (Patil, Budihal, Siddamal, \& Mudenagudi, 2016). This kind of Learning was proved to improve the students' academic achievements and attitudes towards activities (Celik, 2018). It also improved students' motivation (Anwer, 2019.) The learners' role is learning using activities as the critical engine of modern teaching (Learn "How to Learn") in adherence to the principle of learners who create knowledge themselves (child-centered). This is in accordance with the principles of constructionism, learning by doing and practicing in order to learn and solve problems and learning by doing uses "activity" as the main course in teaching and Learning by doing in real life. Every step of the content is self-learning. Everyone in the group is a practitioner. The teacher is the mentor and trainer. However, the activities used must be competent 
in Learning. The content tends to be fun and exciting rather than being repetitive that caused boredom. Therefore, the teacher is an "Activity Designer" who can instantly visualize activities. Teachers must have creative thinking to be able to create new and exciting learning activities at all times. Activities that are created or used must encourage and inspire learners to have curiosity inside their minds. It is the driving force for investigations, searching for knowledge with natural enthusiasm (Kaewchaicharoenkit, 2007; Ministry of Education, 2010; Banchusuwan, 2018; Eka, 2019). Mobile English Learning Center of Loei PESAO 2 had seven learning centers consisted of 1) Cooking: Fruit Salad Making, 2) Fun with Riddles, 3) Healthy Drink from Bamboo Grass, 4) Brick Block Creating, 5) Cooking Mind: Papaya Salad, 6) Fresh Milk Pipo Jelly, and 7) Waste Separating. This curriculum took 35 hours in 4 months. The trainers of the activities were the teachers from the nine targeted schools.

\subsubsection{Data collection tools}

The tools used for collecting data were: 1) After Action Review (AAR) form for recording the performance during the course, and 2) the Curriculum Evaluation Form, which consisted of 2 versions. The first is for teachers and the second for students, which have an open-ended questionnaire and 5-level rating scale. All items of the scale got 1.00 of the IOC index that showed the basic content validity of the research instrument.

\subsection{Procedure and design}

The development of English proficiency and Attitude of primary students using Mobile English Learning Center was operated in 3 steps in 4 months started from June to September 2019 as follows;

\subsubsection{Plan}

1) She is appointing a committee to create a Mobile English Learning Center consisting of school administrators, English teachers, and a supervisor.

2) I am organizing a curriculum conducted by the workshop committee.

3) We are determining the purposes of the course, exploring necessary information about the condition, problems, schools context, and goals of English learning.

4) Creating understanding in the concept of Activity-Based Learning

5) Organizing a sub-group brainstorming to select the topics, determine time structure, learning standards, indicators, content, and learning activities.

6) We are preparing the course conducted by the meeting committee.

\subsubsection{Act and Observe}

1) Implementing the Mobile English Learning Center for seven centers once a week according to the calendar, and followed by another learning center to finish all centers.

2) We are observing the activities according to the schedule conducted by the supervisor and the assessment team.

3) We are conducting the After Action Review (AAR) to reflect the results of implementation, problems, obstacles, and guidelines for the next centers.

\subsubsection{Evaluation and Conclusion}

1) We are conducting an evaluation after completing the activities.

2) Establishing an evaluation framework based on Tyler's Concept consisted of assessing the aims, learning experience, and achievement.

3) I am creating the research tools, checking the psychometric property, and collecting the data with the samples.

\subsection{Data Analysis}


Descriptive statistics were applied for the quantitative data from the questionnaire, while content analysis was applied for the qualitative data from After Action Review.

\section{Phase 2: Quasi-Experimental Research 2.1 Participants}

The participants were 1,338 Prathomsuksa 5 (Grade 5) students, 100 teachers from 157 schools from 6 districts seven learning centers consisting of Erawan, Phakao, Nonghin, Phuluang, Wangsaphung Zone 1, Wangsaphung Zone 1, and Phukradueng. Each learning center was a Primary Education English Resource Center (PEER Center). The sample size was determined using the Krejcie \& Morgan formula at a 95\% confidence level. Purposive sampling was used to select the sample for the quasi-experimental phase in the second semester of the academic year 2019.

\subsection{Measurement}

\subsubsection{Treatment: Mobile English Learning Center}

Mobile English Learning Center, in the second phase, adapted topics and activities to be more interesting, which applied the information from the first time. However, the concept of Mobile English Learning Center still focused on Activity-Based Learning. This Mobile English Learning Center of Loei PESAO 2 had five learning stations consisted of 1) Yok-Krok (Mortar Lifting): How to make Somtam (papaya salad), 2) Let us go shopping, 3) Direction, 4) Day-Care Illnesses, and 5) Save the world. The activities took 35 hours in 3 months. The trainers of the activities were 60 teachers from the 7 PEER Centers and the 11 internship students from Universitas Muhammadiyah Gresik, Indonesia.

\subsubsection{Data collection tools}

The tools used for collecting data for this phase were: 1) After Action Review (AAR) form for recording the performance during the course, 2) English Skills Recording consisted of listening, speaking, reading, and writing skills, and 3) The Curriculum Evaluation Form consisted of 2 versions. The first for teachers and the second for students, which have an open-ended questionnaire and 5-level of the rating scale. All items of the scale got 1.00 of the IOC index, which shows the basic content validity of the research instrument.

\subsection{Procedure and design}

The development of the English proficiency and Attitude of primary students using Mobile English Learning Center in the second phase was operated in 3 steps in 3 months from January to March 2020 as follows;

\subsubsection{Plan}

This step is started by appointing a committee to create a Mobile English Learning Center consisting of school administrators, English teachers, a supervisor, and internship students from Indonesia. The workshop committee organized the curriculum. The participants determined the purposes of the course, explored necessary information about the condition and problems from the first Mobile English Learning Center, followed by selecting topics and determining time structure, learning standards, indicators, content, and learning activities.

\subsubsection{Act and Observe}

The second step is implementing the Mobile English Learning Center for seven centers once a week according to the calendar. The supervisor and the assessment team observed the activities according to the schedule. After the activity was finished, the After Action Review (AAR) was conducted to reflect the results of implementation, problems, obstacles, and guidelines for the next centers.

\subsubsection{Evaluation and Conclusion}

The committee conducted evaluation after completing the activities by establishing an evaluation framework based on Tyler's Concept consisting of assessing the aims, learning 
experience, and achievement followed by creating the research tools, checking the psychometric property, and collecting the data with the samples.

2.4 Data Analysis

Descriptive statistics were applied for the quantitative data from the questionnaire, while content analysis was applied for the qualitative data from After Action Review. In addition, Z-test and one sample t-test were utilized for hypothesis testing of teachers' ability in teaching English, students' Attitude toward English Learning, and English proficiency of the students.

\section{RESULTS AND DISCUSSION}

\section{The Result of Pilot Study Phase}

\subsection{Evaluation Results of Mobile English Learning Center purposes}

The average assessment scores of evaluation results of Mobile English Learning Center purposes by the teachers were at a high level of all items. This meant that the Mobile English Learning Center reached the purposes, as shown in Table 1

Table 1. Evaluation results of Mobile English Learning Center purposes $(n=30)$.

\begin{tabular}{llll}
\hline Items & $\begin{array}{l}\text { Mea } \\
\text { n }\end{array}$ & S.D. & level \\
\hline $\begin{array}{l}\text { 1. Defining objectives so that students have a positive attitude towards } \\
\text { learning English is appropriate. }\end{array}$ & 4.27 & 0.69 & high \\
$\begin{array}{l}\text { 2. The emphasis on English language skills for communication is } \\
\text { appropriate for student development. }\end{array}$ & 3.87 & 0.35 & high \\
$\begin{array}{l}\text { 3. The goal of student development is consistent with the activities used. } \\
\text { 4. The teachers select activities, create curriculum, write plans, and teach } \\
\text { by themselves are useful to them. }\end{array}$ & $\begin{array}{lll}4.60 \\
\text { Average }\end{array}$ & 0.72 & high \\
\hline & $\mathbf{4 . 2 7}$ & $\mathbf{0 . 6 5}$ & high \\
\hline
\end{tabular}

\subsection{Evaluation Results of Mobile English Learning Center process or Learning Experiences}

The result of all evaluation process by the teachers found that the learning experience for the students achieved the objectives that can be seen from the average of the overall assessment at the high level portrayed in table 2 . 
Table 2 Evaluation results of Mobile English Learning Center process or Learning Experiences $(\mathrm{n}=30)$.

\begin{tabular}{|c|c|c|c|}
\hline Items & $\begin{array}{l}\text { Mea } \\
\text { n }\end{array}$ & $\begin{array}{l}\text { S. } \\
\text { D. }\end{array}$ & level \\
\hline $\begin{array}{l}\text { 1. Using Activity Based Learning in learning English was suitable for } \\
\text { students. }\end{array}$ & 4.03 & $\begin{array}{l}0.9 \\
3\end{array}$ & high \\
\hline $\begin{array}{l}\text { 2. Moving to different schools by Mobile English Learning Center } \\
\text { helped encourage students' learning motivation. }\end{array}$ & 4.20 & $\begin{array}{l}0.6 \\
6\end{array}$ & high \\
\hline $\begin{array}{l}\text { 3. Selected activities for creating curriculum and lesson plans were } \\
\text { interesting and beneficial to students. }\end{array}$ & 4.47 & $\begin{array}{l}0.7 \\
3\end{array}$ & high \\
\hline 4. Materials and equipment for organizing activities were appropriate & 4.20 & $\begin{array}{l}0.6 \\
6\end{array}$ & high \\
\hline $\begin{array}{l}\text { 5. Whole group activities, ice breaking, music, games were interesting, } \\
\text { fun and created a good atmosphere in Learning. }\end{array}$ & 4.43 & $\begin{array}{l}0.5 \\
0\end{array}$ & high \\
\hline 6. The frequency of activity and time where appropriate. & 3.47 & $\begin{array}{l}0.9 \\
0\end{array}$ & $\begin{array}{l}\text { modera } \\
\text { te }\end{array}$ \\
\hline Average & 4.13 & $\begin{array}{l}0.5 \\
6\end{array}$ & high \\
\hline
\end{tabular}

\subsection{Students' Attitude}

The evaluation results of the students' attitudes towards learning English through Mobile English Learning Center found that the overall students had the right Attitude at a high level. Students' opinions indicated the trainers organized the fun Mobile English Learning Center. Students wanted more Mobile English Learning Center in the next semester. In addition, students had more friends by participating in the Mobile English Learning Center. These were the highest assessment values of the top three displayed in Table 3. 
Table 3 Evaluation results of the students' attitudes towards learning English through Mobile English Learning Center $(\mathrm{n}=113)$.

\begin{tabular}{|c|c|c|c|}
\hline Items & $\begin{array}{l}\text { Mea } \\
\text { n }\end{array}$ & $\begin{array}{l}\text { S. } \\
\text { D. }\end{array}$ & $\begin{array}{l}\text { leve } \\
\text { l }\end{array}$ \\
\hline $\begin{array}{l}\text { 1. Mobile English Learning Center helped students learned more English } \\
\text { words. }\end{array}$ & 4.11 & $\begin{array}{l}0.7 \\
9\end{array}$ & high \\
\hline $\begin{array}{l}\text { 2. Mobile English Learning Center helped students listened to English } \\
\text { better. }\end{array}$ & 3.73 & $\begin{array}{l}0.7 \\
3\end{array}$ & high \\
\hline 3. Mobile English Learning Center helped students spoke English better. & 3.69 & $\begin{array}{l}0.8 \\
0\end{array}$ & high \\
\hline $\begin{array}{l}\text { 4. Mobile English Learning Center made students were not afraid of } \\
\text { learning English. }\end{array}$ & 3.71 & $\begin{array}{l}0.9 \\
2\end{array}$ & high \\
\hline $\begin{array}{l}\text { 5. Mobile English Learning Center helped students practiced their English } \\
\text { language skills more. }\end{array}$ & 4.07 & $\begin{array}{l}0.7 \\
5\end{array}$ & high \\
\hline $\begin{array}{l}\text { 6. Students learned teamwork skills by participating in Mobile English } \\
\text { Learning Center. }\end{array}$ & 4.12 & $\begin{array}{l}0.8 \\
3\end{array}$ & high \\
\hline $\begin{array}{l}\text { 7. Students had more friends by participating in the Mobile English } \\
\text { Learning Center. }\end{array}$ & 4.27 & $\begin{array}{l}0.8 \\
3\end{array}$ & high \\
\hline $\begin{array}{l}\text { 8. Mobile English Learning Center was interesting and made students want } \\
\text { to join. }\end{array}$ & 4.06 & $\begin{array}{l}0.8 \\
2\end{array}$ & high \\
\hline glish knowledge through participating in Mobile & 3.65 & $\begin{array}{l}0.8 \\
4\end{array}$ & high \\
\hline ng Cent & 4.15 & $\begin{array}{l}0.7 \\
1\end{array}$ & high \\
\hline 11. The trainers organiz & 4.46 & $\begin{array}{l}0.6 \\
8\end{array}$ & high \\
\hline 12. Students liked to le & 4.25 & $\begin{array}{l}0.8 \\
3\end{array}$ & high \\
\hline $\begin{array}{l}\text { 13. Students wanted more Mobile English Learning Center in the next } \\
\text { semester. }\end{array}$ & 4.32 & $\begin{array}{l}0.8 \\
9\end{array}$ & high \\
\hline Average & 4.05 & $\begin{array}{l}0.4 \\
7\end{array}$ & $\begin{array}{l}\text { hig } \\
\text { h }\end{array}$ \\
\hline
\end{tabular}

\section{The Result of Quasi-Experimental Research Phase}

\subsection{Teachers' ability in teaching English}

The effect of Mobile English Learning Center on the teachers' ability in teaching English from the self-evaluation found that teachers were able to teach English at a high level. Mobile English Learning Center promoted participation and cooperation among principals and teachers in the districts. The teachers organized Mobile English Learning Center with fun activities. They have developed themselves and have been more capable of teaching English. Besides, they could select activities, create a curriculum, write lesson plans and teach, as shown in table 4. 
Table 4 Teachers' ability in teaching English $(n=100)$.

\begin{tabular}{|c|c|c|c|}
\hline Items & $\begin{array}{l}\text { Mea } \\
\text { n }\end{array}$ & $\begin{array}{l}\text { S. } \\
\text { D. }\end{array}$ & $\begin{array}{l}\text { leve } \\
\text { l }\end{array}$ \\
\hline $\begin{array}{l}\text { 1. The teachers could select activities, create a curriculum, write lesson } \\
\text { plans and teach by themselves in the Mobile English Learning Center. }\end{array}$ & 4.31 & $\begin{array}{l}0.7 \\
6\end{array}$ & high \\
\hline 2. The teachers organized Mobile English Learning Center with fun. & 4.40 & $\begin{array}{l}0.6 \\
2\end{array}$ & high \\
\hline $\begin{array}{l}\text { 3. Teachers have developed themselves and have been more capable of } \\
\text { teaching English. }\end{array}$ & 4.37 & $\begin{array}{l}0.6 \\
3\end{array}$ & high \\
\hline $\begin{array}{l}\text { 4. Mobile English Learning Center promoted participation and cooperation } \\
\text { among principals and teachers in districts for teaching English. }\end{array}$ & 4.42 & $\begin{array}{l}0.6 \\
2\end{array}$ & high \\
\hline Average & 4.38 & $\begin{array}{l}0.4 \\
5\end{array}$ & $\begin{array}{l}\text { hig } \\
\text { h }\end{array}$ \\
\hline
\end{tabular}

The comparison of teachers' ability in teaching English with the criteria found that the teachers' ability in teaching English was higher than the criteria (Mean > 3.5) with the statistically significance level of .05, as shown in table 5.

Table 5 The comparison of teachers' ability in teaching English with the criteria.

\begin{tabular}{llllll}
\hline Mean & S.D. & df & t & $\begin{array}{l}\text { Mean } \\
\text { Difference }\end{array}$ & sig \\
\hline 4.38 & 0.45 & 99 & 19.377 & 0.875 & $.000 *$ \\
\hline$* \mathrm{p}<.05$ & & & & &
\end{tabular}

\subsection{English Proficiency of the Students}

The proportion between the number of students who were at a right level of English proficiency in listening, speaking, reading, and writing with the number of students who were at an improved level found that the proportion of the number of students who were at the right level of English proficiency was higher than the number of students who were at an improved level with the significant level of .05 for all skills and all learning stations as displayed in table 6 .

Table 6 The proportion comparison of students' English proficiency between good and improved level.

\begin{tabular}{|c|c|c|c|c|c|c|c|}
\hline \multirow{2}{*}{ Learning Station } & \multirow[b]{2}{*}{$\begin{array}{l}\text { English } \\
\text { Proficiency }\end{array}$} & \multirow{2}{*}{ Total } & \multirow{2}{*}{$\begin{array}{l}\text { Good } \\
\text { Numb } \\
\text { er }\end{array}$} & \multicolumn{3}{|c|}{ Improved } & \multirow{2}{*}{ Z-test } \\
\hline & & & & $\begin{array}{l}\text { Perce } \\
\text { nt }\end{array}$ & $\begin{array}{l}\text { Num } \\
\text { ber }\end{array}$ & $\begin{array}{l}\text { Perce } \\
\text { nt }\end{array}$ & \\
\hline 1) Yok-Krok (Mortar & 1. Listening & 1,338 & 843 & 63.00 & 89 & 6.65 & $30.5938^{*}$ \\
\hline Lifting): How to make & 2. Speaking & 1,338 & 735 & 54.93 & 129 & 9.64 & $25.0542 *$ \\
\hline \multirow{2}{*}{ Somtam (papaya salad) } & 3. Reading & 1,338 & 742 & 55.46 & 107 & 8.00 & $26.3751 *$ \\
\hline & 4. Writing & 906 & 352 & 38.85 & 302 & 33.33 & $2.4457 *$ \\
\hline \multirow[t]{4}{*}{ 2) Let's go shopping } & 1. Listening & 1,304 & 844 & 64.72 & 101 & 7.75 & $30.2678 *$ \\
\hline & 2. Speaking & 1,304 & 864 & 66.26 & 131 & 10.05 & $29.5481 *$ \\
\hline & 3. Reading & 1,304 & 865 & 66.33 & 106 & 8.13 & $30.7441^{*}$ \\
\hline & 4. Writing & 903 & 588 & 65.12 & 119 & 13.18 & $22.6112^{*}$ \\
\hline \multirow[t]{4}{*}{ 3) Direction } & 1. Listening & 1,285 & 1049 & 81.63 & 22 & 1.71 & $41.0905^{*}$ \\
\hline & 2. Speaking & 1,285 & 1031 & 80.23 & 44 & 3.42 & $39.4693^{*}$ \\
\hline & 3. Reading & 1,285 & 1066 & 82.96 & 48 & 3.74 & $40.5220 *$ \\
\hline & 4. Writing & 793 & 498 & 62.80 & 85 & 10.72 & $21.5088^{*}$ \\
\hline
\end{tabular}

78 | IJET | Volume. 10, Issue 1. July 2021

Copyright 2021 Wanida Simpol' Phoom Praraksa, Prakit Singthong, and Paulina, M. Pd are licensed under Creative

Commons Atrribution-ShareAlike 4.0 International License. 


\begin{tabular}{llllllll}
\hline 4) Day-Care Illnesses & 1. Listening & 1,334 & 859 & 64.39 & 156 & 11.69 & $28.0336^{*}$ \\
& 2. Speaking & 1,334 & 888 & 66.57 & 164 & 12.29 & $28.6816^{*}$ \\
& 3. Reading & 1,334 & 903 & 67.69 & 168 & 12.59 & $29.0291^{*}$ \\
& 4. Writing & 1,296 & 738 & 56.94 & 230 & 17.75 & $20.6277^{*}$ \\
\hline 5) Save the world & 1. Listening & 1,334 & 1030 & 77.21 & 60 & 4.50 & $38.2030^{*}$ \\
& 2. Speaking & 1,334 & 1055 & 79.09 & 66 & 4.95 & $38.7919^{*}$ \\
& 3. Reading & 1,334 & 1064 & 79.76 & 61 & 4.57 & $39.3219^{*}$ \\
& 4. Writing & 1,055 & 756 & 71.66 & 72 & 6.82 & $30.4957^{*}$ \\
\hline
\end{tabular}

$* \mathrm{p}<.05$

2.3 Students' Attitude towards learning English through Mobile English Learning Center 2.3.1 Descriptive statistics of students' attitude towards learning English through Mobile English Learning Center

The students' attitudes towards learning English through Mobile English Learning Center found that the overall students had a good attitude at a high level. Students' opinions indicated that the trainers organized Mobile English Learning Center with fun activities. Mobile English Learning Center helped students learned more English words. In addition, Mobile English Learning Center was useful for students. These were the highest assessment values of the top three, as displayed in Table 7. 
Table 7 Descriptive statistics of the students' attitudes towards learning English through Mobile English Learning

Center $(n=395)$.

\begin{tabular}{|c|c|c|c|}
\hline Items & $\begin{array}{l}\text { Mea } \\
\text { n }\end{array}$ & $\begin{array}{l}\text { S. } \\
\text { D. }\end{array}$ & $\begin{array}{l}\text { leve } \\
\text { l }\end{array}$ \\
\hline $\begin{array}{l}\text { 1. Mobile English Learning Center helped students learned more English } \\
\text { words. }\end{array}$ & 4.24 & $\begin{array}{l}0.7 \\
5\end{array}$ & high \\
\hline $\begin{array}{l}\text { 2. Mobile English Learning Center helped students listened to English } \\
\text { better. }\end{array}$ & 3.95 & $\begin{array}{l}0.8 \\
5\end{array}$ & high \\
\hline 3. Mobile English Learning Center helped students spoke English better. & 3.86 & $\begin{array}{l}0.9 \\
1\end{array}$ & high \\
\hline $\begin{array}{l}\text { 4. Mobile English Learning Center made students were not afraid of } \\
\text { learning English. }\end{array}$ & 3.82 & $\begin{array}{l}0.9 \\
1\end{array}$ & high \\
\hline $\begin{array}{l}\text { 5. Mobile English Learning Center helped students practiced their English } \\
\text { language skills more. }\end{array}$ & 4.09 & $\begin{array}{l}0.8 \\
2\end{array}$ & high \\
\hline $\begin{array}{l}\text { 6. Students learned teamwork skills by participating in Mobile English } \\
\text { Learning Center. }\end{array}$ & 4.00 & $\begin{array}{l}0.8 \\
7\end{array}$ & high \\
\hline $\begin{array}{l}\text { 7. Students had more friends by participating in the Mobile English } \\
\text { Learning Center. }\end{array}$ & 3.92 & $\begin{array}{l}1.0 \\
2\end{array}$ & high \\
\hline $\begin{array}{l}\text { 8. Mobile English Learning Center was interesting and made students want } \\
\text { to join. }\end{array}$ & 3.85 & $\begin{array}{l}0.9 \\
3\end{array}$ & high \\
\hline Mobile & 3.91 & $\begin{array}{l}0.8 \\
6\end{array}$ & high \\
\hline$G_{-2}+5$ & 4.22 & $\begin{array}{l}0.8 \\
4\end{array}$ & high \\
\hline 11. $\mathrm{T}$ & 4.32 & $\begin{array}{l}0.7 \\
8\end{array}$ & high \\
\hline 12. Students liked to le: & 3.94 & $\begin{array}{l}0.8 \\
9\end{array}$ & high \\
\hline $\begin{array}{l}\text { udents wanted more Mobile English Learning Center in the next } \\
\text { er. }\end{array}$ & 4.08 & $\begin{array}{l}0.9 \\
9\end{array}$ & high \\
\hline Average & 4.02 & $\begin{array}{l}0.5 \\
4\end{array}$ & $\begin{array}{l}\text { hig } \\
\text { h }\end{array}$ \\
\hline
\end{tabular}

\subsubsection{The comparison of students' Attitude with the criteria}

The comparison of students' Attitudes with the criteria found that the students' Attitude was higher than the criteria (Mean > 3.5) with the statistically significance level of .05, as shown in table 8.

Table 8 The comparison of students' Attitudes with the criteria.

\begin{tabular}{llllll}
\hline Mean & S.D. & df & t & $\begin{array}{l}\text { Mean } \\
\text { Difference }\end{array}$ & sig \\
\hline 4.02 & 0.54 & 394 & 19.082 & 0.516 & $.000 *$ \\
\hline $\mathrm{p}<.05$ & & & & &
\end{tabular}

\section{Discussion and Conclusion}

\section{Teachers' ability in teaching English}


The effect of Mobile English Learning Center on the teachers' ability in teaching English from self-evaluation concluded that teachers were able to teach English at a high level. The comparison of teachers' ability in teaching English with the criteria also concluded that the teachers' ability in teaching English was higher than the criteria (Mean > 3.5) with a statistically significant level of .05. This proved Mobile English Learning Center has developed based on teachers' involvement in self-development methods and based on a belief in the potential of people that can be developed. Teachers have collaborated to create curriculums for their own learning plans, with the development of English teaching potential based on Activity-Based Learning. As a result, teachers have teaching techniques and learning activities that stimulate student interest. They have changed teaching methods to be proactive (Active Learning) that encourage students to learn English. In addition, English teachers have the opportunity to practice using English with foreign internship students in real situations. This makes them more confident in using English for communication to improve their English teaching. However, teachers' ability to teach English still requires continuous development in the long run because their ability still does not reach the development goals. Teachers are important people for the quality of education. This is consistent with the research by Mckinsey \& Company (2010), which found that among the measurements to improve the quality of education being carried out around the world, the most important factor is "teacher quality" as noted that the quality of an education system cannot exceed the quality of its teachers. Teachers must also develop active Learning to be more effective because the change in teaching behavior takes time for teachers to understand clearly. Moreover, they have to practice changing their roles from the informant to activity designer and facilitate to encourage students to learn in a meaningful way. Therefore, it is necessary to develop the ability of proactive teaching (Kaewchaicharoenkit, 2007; Ministry of Education, 2010; Banchusuwan, 2018; Eka, 2019).

\section{English Proficiency of the Students}

The proportion between the number of students who were at a right level of English proficiency in listening, speaking, reading, and writing with the number of students who were at an improved level concluded that the proportion of the number of students who were at the right level of English proficiency was higher than the number of students who were at an improved level with the significant level of .05 for all skills and all learning stations. Most probably, the Mobile English Learning Center focuses on Activity Based Learning (Eka, 2019) which is congruent with the concept of active learning, which is the learning process that the learners act and use the thinking process about what they have done. The learner is the center of Learning. Activities must reflect the needs of learners' development and emphasize the implication in real life of learners (Kaewchaicharoenkit, 2007). In addition, Deepaen (2010) has suggested the ways to improve the teaching and Learning of English effectively should encourage students to have the opportunity to practice using language in an environment that is conducive to the use of language. Therefore, creating good interaction between teachers and students and between students and friends is necessary. Building the rightAttitude towards English, creating motivation for achievement, and providing students the opportunity to learn English with native speakers are some ways to do. This supported the internship program that the internship students who were trainers encouraged students to develop their English proficiency. This is consistent with Phayakmak (2008), who found that the factors affecting the teaching andLearningg in the classroom for students were attention to Learning and practice both in and outside the class. Another is cooperation in various activities, including various teaching techniques. Encouraging students to interact and be assertive and creating a fun and friendly atmosphere in learning activities should be carried out. There are a variety of activities promoting the development of communication capabilities and providing opportunities for participation. The atmosphere of the physical and psychological classes in the school, including media support and learning resources, is also important. Moreover, Ketrueng, Chamchoi \& 
Chatruprawin (2017) showed that factors of success in managing English learning for students include 1) raising awareness among administrators, teachers, and educational personnel to recognize the importance of using English for communication 2) promoting administrators, teachers, and educational personnel to develop their knowledge and skills in using English for communication.

\section{Students' Attitude towards learning English through Mobile English Learning Center}

The students' attitudes towards learning English through Mobile English Learning Center concluded that the overall students had a good attitude at a high level. Students' opinions indicated that the trainers organized Mobile English Learning Center with fun activities. Mobile English Learning Center helped students learned more English words. In addition, Mobile English Learning Center was useful for students. The comparison of students' Attitudes with the criteria found that the students' Attitude was higher than the criteria (Mean > 3.5) with the statistically significance level of .05. This happens when attitudes play an important role because success in the learning process depends on the Attitude of the learners towards the native speakers. Prasertsang (1999) and Plianpoo (1999) agreed that in Learning, the student's Attitude towards studying, subjects, or teachers is very important. If students have good attitudes, they will study hard, like learning those subjects and making learning more effective. On the other hand, if students have a bad attitude, they will feel bored and do not want to study that subject. This causes learning to be ignored at schools and may lead to academic failures. Therefore, teachers should perform good attitudes for students in order to make them feel good and comfortable with the teachers which can lead to love learning and love coming to school rustling on success in their studies. Deepaen (2010) has suggested the ways to improve the teaching and Learning of English effectively is encouraging students to have good interaction between teachers and students and also between students and friends. Furthermore, the teachers should build a good attitude toward English, create achievement motivation and provide students the opportunity to learn English with native speakers. In addition, Phayakmak (2008) suggested that likes and aptitudes in English, family support, basic knowledge, and extra education were factors that influenced English learning. In addition, good relationships between teachers and students and the relaxed climate of teaching also affected the students' Attitudes. Furthermore, Mobile English Learning Center was benefited from the trainers who were the internship students from Indonesia because they motivated students to participate in the activities and made students actively learn English in a fun way. This can lead students to have a good attitude towards English learning.

\section{CONCLUSION}

Mobile English Learning Center suggested for development as follows:

1. This activity has a strong point in terms of developing students to have a good attitude towards English learning. It is a fun activity for students. There are foreign students who use English all the time in organizing activities which can help to create the motivation to learn English very well. Therefore, every English skill development activity should have native speakers or foreigners joining the activity to achieve more learning objectives.

2. The teachers' ability to use English is an important factor that leads to learning objectives achievement. Having foreign students organize activities help motivate teachers to be enthusiastic about improving their English skills and also encourages teachers to become more confident in using English. As a result, the development of teachers by working with foreigners or native speakers as a means of development corresponds to the real situations and creates awareness of selfdevelopment for teachers. 
3. Implementation is the heart of activity-based Learning. Encouraging students to take action on their own is an important factor for successful Learning. Therefore, the teacher should give the students the opportunity to participate in the learning activities as much as possible.

4. In the future, Mobile English Learning Center should be managed to increase the budget, time, and support resources. It is necessary to mobilize additional resources to improve English skills development activities more effectively and efficiently. 


\section{REFERENCES}

Anwer, F. (n.d.). Activity-Based Teaching , Student Motivation and Academic Achievement. 6(1), 154-170.

Banchusuwan, P. (2018). Active Learning Approach in Enhancing Knowledge to Understand Politics and Democracy in Comparison. Electronic Journal of Open and Distance Innovative Learning (e-JODIL), 8(1), 166-190.

Biznews, B. (2016). Thai Children Do Not Progress in English. Who is the Problem? http://www.moe.go.th/moe/th/news/detail.php?NewsID=45063\&Key=hotnews

Changwong, K., Sukkamart, A., \& Sisan, B. (2018). Critical Thinking Skill Development: Analysis of a New Learning Management Model for Thai High Schools. Journal of International Studies, 11(2), 37-48. https://doi.org/10.14254/2071-8330.2018/11-2/3

Charoenpho, A., Supanyo, W., \& Tinnangwattana, W. (2016). Self-development Approach to Empower English Teaching for Border Patrol Police School Teachers. Kasetsart Journal of Social Sciences, 37, 75-85.

Deepaen, W. (2010). Factors Affecting English Learning Achievement of Grade 9 Students in Schools Under Loei Primary Educational Service Area Office Using the Multilevel Analysis. Loei Rajabhat University.

Doungprom, U., Phusee-on, S., \& Prachanant, N. (2016). The development desire of Non-English major teachers in small rural primary schools in Thailand: Participatory action research. Academic Journals, 11(16), 1612-1621. https://doi.org/10.5897/ERR2015.2415

Education, C. O. of the B. (2014). Practical Guidelines Along The Announcement of The Ministry of Education on The Policy of English Learning Reform. Chamchuri Products.

Education, M. (2010). Activity-Based Learning. https://www.moe.go.th/moe/th/news/detail.php?NewsID=16207\&Key=news15

Education, M. of. (2017). An Annual Government Action Plan 2017 of The Ministry of Education. Office of Policy and Strategy, Office of the Permanent Secretary.

Eka, S. (2019). Activity Based Learning. Https://Www.Krumontree.Com/Www/Documents/137Abl-Activity-Based-Learning.Html.

Grenier, G. (2015). The value of language skills. November, 1-10. https://doi.org/10.15185/izawol.205

Gunawan, I. (2017). Indonesian Curriculum 2013: Instructional Management, Obstacles Faced by Teachers in Implementation and the Way Forward. Atlintis Press, 128(Icet), 56-63. https://doi.org/10.2991/icet-17.2017.9

Kaewchaicharoenkit, N. (2007). Teacher Role with Active Learning. http://edu.nsru.ac.th/2011/files/knowlage/17-14-19_22-07-2014_2-1.pdf

84 | IJET| Volume. 10, Issue 1. July 2021 Copyright 2021 Wanida Simpol' Phoom Praraksa, Prakit Singthong, and Paulina, M. Pd are licensed under Creative Commons Atrribution-ShareAlike 4.0 International License. 
Ketruang, W., Chamchoi, S., \& Chatruprawin, C. (2017). The Learning Management Model of Communicative English for Students in Small Sized Educational Opportunity Expansion Schools. Journal of Education Naresuan, 19(3), 313-328.

Leeahtam, P. (2020). 101 Policy Forum: Break through The Educational Reform through The Inequality. https://www.the101.world/101-policy-forum-ep01/

Mckinsey, C. \&. (2010). Measures to Improve The Quality of Education in Office for Promotion of The Learning Society and The Quality of Youth: The Project for Synthesis of Knowledge in Abroad Education Reform. Thammasat University.

Office, L. P. E. (2018). Government Action Plan for The Fiscal Year 2019.

Patil, U., Budihal, S. V, Siddamal, S. V, \& Mudenagudi, U. K. (2016). Activity Based Teaching Learning : An Experience Activity Based Teaching Learning : An Experience. September 2018. https://doi.org/10.16920/jeet/2016/v0i0/85433

Phayakmak, W. (2008). Factors Affecting Communicative English Competency of English Program Students: Multiple Case Studies. Chulalongkorn University.

Plianpoo, P. (1999). Educational Psychology (5th ed.). King Mongkut's University of Technology Thonburi.

Prasertsang, C. (1999). Teaching Psychology. Rambhai Barni Rajabhat Institute.

Profile, S. E. E. (2018). The Effects of Activity Based Learning on Sixth Grade Students' Achievement and Attitudes towards Mathematics Activities The Effects of Activity Based Learning on Sixth Grade Students' Achievement and Attitudes towards Mathematics Activities. June. https://doi.org/10.29333/ejmste/85807

Sriyai, W. (2012). Revealing Thai Teachers Destroy The Courage of Children, Not Accepting Differences - Opinions Affects Bad Results in "English." https://www.tcijthai.com/news/2012/11/scoop/1677. 